\title{
Mitigating Soil Salinity Stress with Gypsum and Bio-Organic Amendments: A Review
}

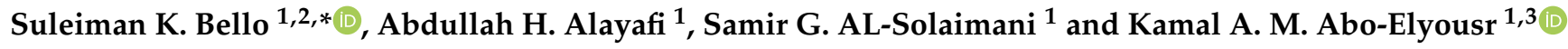 \\ 1 Department of Arid Land Agriculture, Faculty of Meteorology, Environment and Arid Land Agriculture, \\ King Abdul-Aziz University, Jeddah 80200, Saudi Arabia; alayafi006@gmail.com (A.H.A.); \\ salsolaimani@hotmail.com (S.G.A.-S.); kaaboelyousr@agr.au.edu.eg (K.A.M.A.-E.) \\ 2 Department of Soil Science, Faculty of Agriculture/Institute for Agricultural Research, \\ Ahmadu Bello University, Zaria P.M.B. 1044, Kaduna State, Nigeria \\ 3 Department of Plant Pathology, Faculty of Agriculture, University of Assiut, Assiut 71526, Egypt \\ * Correspondence: bellosuleimank@gmail.com; Tel.: +966-572006973
}

Citation: Bello, S.K.; Alayafi, A.H.; AL-Solaimani, S.G.; Abo-Elyousr, K.A.M. Mitigating Soil Salinity Stress with Gypsum and Bio-Organic Amendments: A Review. Agronomy 2021, 11, 1735. https://doi.org/ 10.3390/agronomy11091735

Academic Editor: Vijay Joshi

Received: 29 July 2021

Accepted: 26 August 2021

Published: 29 August 2021

Publisher's Note: MDPI stays neutral with regard to jurisdictional claims in published maps and institutional affiliations.

Copyright: (C) 2021 by the authors. Licensee MDPI, Basel, Switzerland. This article is an open access article distributed under the terms and conditions of the Creative Commons Attribution (CC BY) license (https:// creativecommons.org/licenses/by/ $4.0 /)$.

\begin{abstract}
Salinity impedes soil and crop productivity in over 900 million ha of arable lands worldwide due to the excessive accumulation of salt $(\mathrm{NaCl})$. To utilize saline soils in agriculture, halophytes (salt-tolerant plants) are commonly cultivated. However, most food crops are glycophytes (salt-sensitive). Thus, to enhance the productivity of saline soils, gypsum $\left(\mathrm{CaSO}_{4} \cdot 2 \mathrm{H}_{2} \mathrm{O}\right)$ as well as bio-organic (combined use of organic materials, such as compost and straw with the inoculation of beneficial microbes) amendments have been continuously recognized to improve the biological, physical and chemical properties of saline soils. $\mathrm{CaSO}_{4} \cdot 2 \mathrm{H}_{2} \mathrm{O}$ regulates the exchange of sodium $\left(\mathrm{Na}^{+}\right)$for calcium $\left(\mathrm{Ca}^{2+}\right)$ on the clay surfaces, thereby increasing the $\mathrm{Ca}^{2+} / \mathrm{Na}^{+}$ratio in the soil solution. Intracellularly, $\mathrm{Ca}^{2+}$ also promotes a higher $\mathrm{K}^{+} / \mathrm{Na}^{+}$ratio. Simultaneously, gypsum furnishes crops with sulfur (S) for enhanced growth and yield through the increased production of phytohormones, amino acids, glutathione and osmoprotectants, which are vital elicitors in plants' responses to salinity stress. Likewise, bio-organic amendments improve the organic matter and carbon content, nutrient cycling, porosity, water holding capacity, soil enzyme activities and biodiversity in saline soils. Overall, the integrated application of gypsum and bio-organic amendments in cultivating glycophytes and halophytes is a highly promising strategy in enhancing the productivity of saline soils.
\end{abstract}

Keywords: salinity; gypsum; sulfur; halophytes; glycophytes; climate change; bio-organic amendments; plant growth promoting microorganisms; compost; straw

\section{Introduction}

Recent and past data have shown that global agricultural production is continuously being impeded by salinity [1-3]. Soil salinity, which arises as a result of excessive accumulation of sodium chloride $(\mathrm{NaCl})$, sodium sulfate $\left(\mathrm{Na}_{2} \mathrm{SO}_{4}\right)$, sodium carbonate $\left(\mathrm{Na}_{2} \mathrm{CO}_{3}\right)$, calcium chloride $\left(\mathrm{CaCl}_{2}\right)$ and magnesium chloride $\left(\mathrm{MgCl}_{2}\right)$, is a major environmental constrain hindering crop productivity and growth in the terrestrial ecosystem [4,5]. Salinity degrades the soil vis-à-vis its physical, biological and chemical properties, thus, adversely reduces soils capability in meeting the needs of the required increase in global food security. Worldwide, over 900 million ha of arable lands and 6\% of total land area are affected by salinity [6-8]. Saline soils arising from natural and/or human-induced processes are diverse in nature and widely distributed in all climatic conditions [1,9]. From the arid to the humid regions of the world, all soil types could be impacted by salinity [10].

As increased global food security is a much-needed goal to feed the burgeoning population of the world, it has become very pertinent to keep developing suitable and efficient techniques to reclaim salt-affected soils [11]. One of the main strategies of sustaining plant production on saline soil is the leaching of the soil with non-saline water to remove excess salts from the soil surface. However, leaching and the development of efficient 
drainage systems are not feasible in places with low water supply, consume a lot of time, expensive and improper disposal of drainage water may negatively affect the environment. Another strategy for enhancing the productivity of saline soils is through the cultivation of salt-tolerant (halophytes) species of plants. Halophytes, such as Salicornia europaea, Thellungiella salsuginea (a typical halophyte) and Atriplex spp., produce their optimal yields at high concentrations (up to $1000 \mathrm{mM} \mathrm{L}^{-1}$ ) of $\mathrm{NaCl}$ [12-14]. However, most food crops are salt-sensitive (glycophytes) except for a few. Different studies have demonstrated that food crops, such as tomato [15], rice [4], wheat [16], barley [17] and faba bean [18], are susceptible to salt stress. Glycophytes growth is stunted or eradicated at low concentrations $\left(\leq 200 \mathrm{mM} \mathrm{L}^{-1}\right.$ ) of $\mathrm{NaCl}$ [13]. Thus, it has become more pertinent to find ways of improving the adaptability and yield of glycophytes in saline soil conditions.

Several studies aimed at the management of salinity have looked into enhancing the capacity of food crops to maintain growth and productivity under soil salinity stress conditions. Most of these efforts are targeted at maintaining optimal $\mathrm{K}^{+} / \mathrm{Na}^{+}$ratios, essential nutrient concentrations in the soil solution and soil organic matter as well as increased antioxidants and amino acids production in plants [8,19]. In this regard, gypsum has been reported several times to sustain optimal $\mathrm{K}^{+} / \mathrm{Na}^{+}$and $\mathrm{Ca}^{2+} / \mathrm{Na}^{+}$ratios, reduced $\mathrm{pH}$ as well as furnish crops with the required $\mathrm{S}$ nutrition in saline soils $[11,18,20,21]$. Through the provision of $S$, gypsum increases plants' tolerance and resistance to both biotic and abiotic stress factors by aiding the synthesis of proteins, chlorophyll-containing compounds as well as an increased uptake of $P$ and $N$ [21,22]. In addition, the combined use of biological (beneficial microbes) and organic materials (e.g., compost and straw) as bioorganic amendments with gypsum has a great potential in ameliorating saline soils. This combination could improve the soil structure, increase the soil organic carbon, humus and nutrient contents, which are the most growth-constraining factors in saline soils. In addition, the use of bio-organic amendments in saline soils improves soil biodiversity to enhance plants' tolerance to salinity stress. In a recent global study, it has been concluded that among all strategies deployed in managing soil salinity, the integrated use of soil amendments, biological and organic materials are the most promising with significant impacts on food security [23]. Thus, this review seeks to shed more light on the roles of gypsum and bio-organic amendments in the amelioration of salinity stress at the plant-soil interface.

\section{Effect of Salinity on Soil Properties and Productivity}

Salinity causes a great decline in the capacity of soil use for agricultural productions. In saline field conditions, the reactions at the soil-plant interface are complex and controlled by soil water dynamics, $\mathrm{pH}$ in relation to the solubility of salts in the rhizosphere, nutrient availability, soil structural stability, organic matter or humus content and redox potential [10]. Soil salinity reduces the soil organic matter content, soil water-holding capacity, water infiltration, weakens the soil structure and disrupts the soil aggregate stability [24-26]. Other common negative impacts of salinity on soil properties include increased soil $\mathrm{pH}$, exchangeable sodium percentage (ESP) and sodium adsorption ratio (SAR), as well as reduced cation exchange capacity (CEC) and soil microbial community [26-28]. Due to high $\mathrm{Na}^{+}$concentrations in the soil solution or at the cations exchange site, salinesodic soil may arise, causing loss of inherent soil quality [27,29]. Saline-sodic soils are negatively affected by high salt concentrations with an ESP and SAR of greater than $15 \%$ and $13 \mathrm{mmol}_{\mathrm{C}} \mathrm{kg}^{-1}$, respectively.

Other types of soils that are associated with salinity include sodic soils with $\mathrm{pH} 6-8$; alkaline-saline, alkaline-sodic, alkaline saline-sodic soils with $\mathrm{pH}>8$; acidic-saline, acidic-sodic and acidic saline-sodic soils with $\mathrm{pH}<6$ [10]. Another index of soil salinity is electrical conductivity (EC) of $\geq 4 \mathrm{dS} / \mathrm{m}$ which is equivalent to $40 \mathrm{mM} \mathrm{NaCl}$ [5]. Thus, soil salinity results in a toxic accumulation of $\mathrm{Na}^{+}$, which creates osmotic stress in plants, eventually leading to cell death due to low water uptake [15]. This excessive accumulation of $\mathrm{Na}^{+}$thereby leads to plant wilting even under adequate soil moisture [18]. Salinity also negatively impacts soil biological characteristics, such as soil enzyme activity, respira- 
tion, microbial population, diversity and biomass [28]. These impacts, in turn, affect soil productivity through reduced nutrient cycling, carbon fixation, porosity and tolerance to biotic stress factors (e.g., soil-borne diseases) in saline soils. Therefore, agricultural productivity under salinity stress significantly declines by reductions in plant vigor, growth, development and yield [30]. A general summary of the characteristics of salt-affected soils is presented in Figure 1 below.

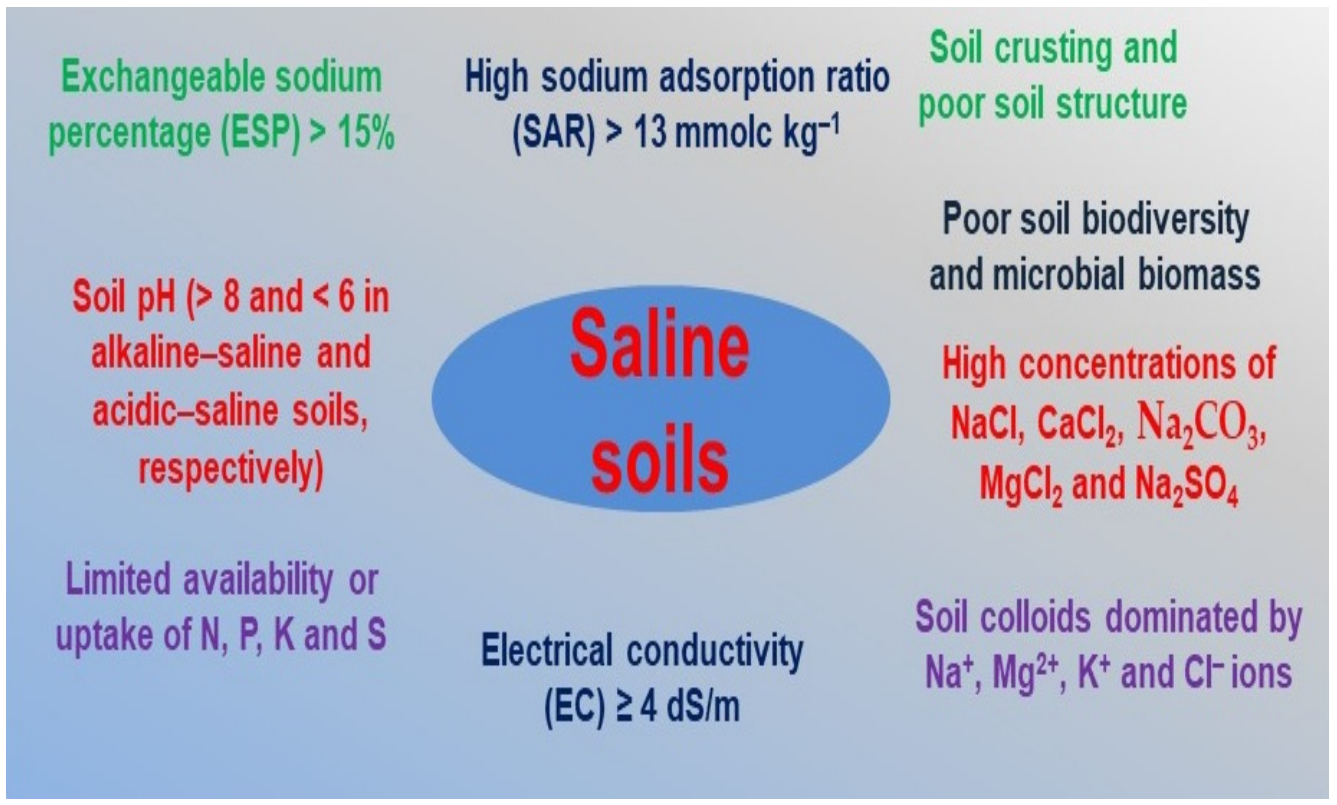

Figure 1. A general summary of the characteristics of salt-affected soils.

Prominent causes of increasing global soil salinity are high surface evaporation, low amount of rainfall, increased global temperature, movement of saline groundwater to the soil surface, salt deposition on soils from oceans and the accumulation of salt minerals $[5,10,31,32]$. These causes extend over areas that are naturally or anthropogenically saline. Apart from the seashores, naturally saline soils (primary salinization) are mostly found in the arid to semiarid regions of the world due to the characteristics of the prevailing landscape and weather conditions, such as low rainfall, high temperature and evaporation. Anthropogenically saline soils (secondary salinization) are mostly found in the humid to sub-humid regions due to improper agricultural practices that degrade the soil. Intensive agriculture, which exerts more pressure on arable lands to increase yield per unit area through excessive or improper irrigation, fertilizer and pesticide applications, also leads to soil salinization [33].

On a global estimate, agricultural production is reliant on irrigation over rainfalldependent agriculture because it sustains continuous crop production year-round [5] However, the effect of salinity is more pronounced in irrigated agriculture as a large proportion $(20 \%)$ of the soils is salt-affected [5,34]. Of all anthropogenic causes of soil salinization, excessive irrigation of crops with salt-ladened water, coupled with an inadequate drainage system, ranks foremost as it raises the water table and leaves salts deposited on soils after the evaporation of water [13,32]. Without proper monitoring, irrigation water often contains a high concentration of salts, which increases the susceptibility of soils and crops to salinity stress [35]. The excessive uptake of these salts leads to toxicity, which has negative impacts on growth and productivity by reducing the availability and uptake of water and essential nutrients, such as nitrogen $(\mathrm{N})$ and phosphorus $(\mathrm{P})$ [36-38].

\section{Plants Response to Salinity Stress}

Over time, plants have evolved several ways to mitigate salinity stress. Soil salinity affects the biochemical, physiological and morphological processes of plants [39]. This 
effect is manifested at two different levels, namely the osmotic and ionic phases [12]. The osmotic phase occurs immediately on the uptake of excess salt and causes a reduction in plant water uptake, the water content of leaves, production of carotenoids and chlorophyll contents, as well as overall plant growth $[4,12]$. The ionic phase is characterized by salinity-induced accumulation of $\mathrm{Na}^{+}$and $\mathrm{Cl}^{-}$, which leads to ion imbalance (higher $\mathrm{Na}^{+} / \mathrm{K}^{+}$ratio), leaf necrosis and plant senescence earlier than the attainment of physiological maturity $[12,40,41]$. It has been suggested that at a low level of EC $\left(\leq 7.0 \mathrm{dS} \mathrm{m}^{-1}\right)$, the ionic phase predominates after about three weeks of plant growth, while the osmotic phase predominates throughout the plant life cycle at a high level of EC $\left(30 \mathrm{dS} \mathrm{m}^{-1}\right)$ [10]. Mitigating $\mathrm{Na}^{+}$uptake has been suggested to be the most important strategy in the resistance of plants to salinity stress [42]. $\mathrm{Na}^{+}$uptake via the root's plasma membrane is facilitated by the activities of high-affinity potassium transporters (HKTs), aquaporins and the nonselective cation channels (NSCCs) [42-44]. In saline conditions, NSCCs do not differentiate between $\mathrm{Na}^{+}$and $\mathrm{K}^{+}$due to their similar ionic radii, while class I HKTs are $\mathrm{Na}^{+}$-specific transporters and Class II HKTs are co-transporters of $\mathrm{Na}^{+}$and $\mathrm{K}^{+}[43,45]$. Thus, NSCCs tend to favor the higher uptake of $\mathrm{Na}^{+}$, leading to $\mathrm{K}^{+}$deficiency and $\mathrm{Na}^{+}$toxicity [43]. To adjust appropriately, the excess $\mathrm{Na}^{+}$entering the cytoplasm must be removed, and further influx through the roots must be regulated. For an increased understanding of $\mathrm{Na}^{+}$uptake and efflux by plants in saline conditions, more detailed studies would need to unravel the several mechanisms involved in the reduction of $\mathrm{Na}^{+}$influx into root cells, selectivity for $\mathrm{Na}^{+}$over $\mathrm{K}^{+}$uptake, compartmentalization of $\mathrm{Na}^{+}$into vacuoles by $\mathrm{Na}^{+} / \mathrm{H}^{+}$ antiporters, redistribution and utilization of $\mathrm{Na}^{+}$within the plant and increased $\mathrm{Na}^{+}$efflux from root cells via the salt overly sensitive (SOS) pathway $[42,43,46,47]$. There are also indications of the presence of putative P-type ATPases that could facilitate the efflux of $\mathrm{Na}^{+}$ from plants and needs to be extensively studied [43]. Several reviews [5,12,42,43,46-48] could be consulted for a better understanding and the current state of knowledge on the mechanisms and processes involved in $\mathrm{Na}^{+}$uptake and efflux by plants.

In response to higher concentrations of $\mathrm{NaCl}$ in the soil, $\mathrm{Na}$ uptake by the roots is increased while $\mathrm{P}, \mathrm{N}, \mathrm{Ca}, \mathrm{Mg}$, and $\mathrm{K}$ uptake is lowered significantly, leading to the disruption of the intracellular ionic balance [49]. Furthermore, excessive uptake of $\mathrm{Na}^{+}$ and $\mathrm{Cl}^{-}$causes hyperosmotic stress, resulting in decreased water potential, which limits water uptake by plant roots [47]. In a wheat crop grown on saline soil, the reduction in water uptake is heightened during the flowering and grain filling period and thus having a great adverse effect on the final yield [10]. In adaptation to reduced water uptake, plants reduce their leaf area and stomatal conductance to prevent water loss through transpiration. Leaves become small with thicker cuticles due to the reduction in cell division and elongation imparted by osmotic stress [12]. Thus, salinity negatively impacts photosynthesis by lowering carbon (C) assimilation and crops water use efficiency, thereby leading to physiological drought and ion toxicity in plants $[3,5,50]$.

$\mathrm{K}^{+}$maintains the integrity of the cell and its membrane, and it is the most abundant cation in the plant cell [13]. Due to the ionic similarity of $\mathrm{Na}^{+}$and $\mathrm{K}^{+}$, salinity stress causes $\mathrm{Na}^{+}$to replace $\mathrm{K}^{+}$in the cells, thereby disrupting key metabolic processes and enzymatic activities regulated by $\mathrm{K}^{+}[5,51]$. For example, $\mathrm{Na}^{+}$replaces $\mathrm{K}^{+}$in the ribosome, thereby affecting protein production [12]. Despite the ability of halophytes to withstand the accumulation of $\mathrm{Na}^{+}$, their cytosolic enzymes are as sensitive to $\mathrm{Na}^{+}$as glycophytes [13]. To maintain growth with a high concentration of $\mathrm{Na}^{+}$intracellularly, halophytes channel excess $\mathrm{Na}^{+}$ions in the cytoplasm to the vacuole, where they are rendered redundant and unharmful [41]. Other mechanisms of sustaining growth under salinity stress include the accretion of low molecular weight organic compounds and/or solutes, such as osmolytes (e.g., polyols, betaines and amino acids), to enhance sufficient water uptake and increased production of antioxidants [13,15,38,41,52]. The organic solutes also counteract the effect of inorganic solutes, such as $\mathrm{Na}$ and $\mathrm{Cl}$ ions in the cells [13]. Additionally, salt-tolerant plants detect salinity stress at an early stage and can evolve appropriate responses, such as changes in signal transductions and metabolism, to cope with the abiotic stress, unlike 
glycophytes [18,53]. For instance, $\mathrm{Na}^{+}$transporters in halophytes regulate the amount of $\mathrm{Na}$ ion entering the xylem particularly before getting to the shoots, where most photosynthetic apparatus are situated [5].

In response to salinity and the consequent osmotic-induced stress, plants produce osmoprotectants, hormones, proteins and antioxidants that scavenge oxygen-free radicals to enhance tolerance and survival $[13,15,48]$. Likewise, the reception of salinity stress stimulus in plants results in a reduced stomatal conductance regulated by increased synthesis of abscisic acid [41]. The production of phytohormones is one of the key strategies with which plants regulate their responses to salinity stress. Phytohormones confer salt tolerance to plants by modulating the uptake of excessive salt, increasing carbon dioxide $\left(\mathrm{CO}_{2}\right)$ fixation, promoting plant growth and regulating the efficient distribution of absorbed salts for improved plant growth [16,54]. For a detailed account of the molecular, biochemical and physiological tolerance mechanisms regulating salinity stress in plants, the studies of Almeida et al. [5], Flowers and Colmer [55] and Zhu [13] could be consulted. A close study of the mechanisms of salt tolerance in halophytes could give insights into enhancing salinity tolerance in glycophytes. Salt tolerance mechanisms could be modeled in halophytes through molecular crop breeding and genome editing. Conventional breeding could also be used in the selection of crop genotypes with high potential for salinity tolerance. The provision of a soil condition where the uptake of essential nutrients (N, P and K) could be favored against the uptake of Na would also go a long way in enhancing glycophytes growth and yield in saline soils.

\section{Importance of Gypsum in Saline Soils}

Saline soils are diverse in nature and require specific strategies, such as the application of sulfur-containing compounds such as gypsum, to aid their management and reclamation for long-term productivity [22,56]. Gypsum application is foremost among the widely known methods of reclaiming salt-affected soils; other related amendments include elemental $\mathrm{S}$, sulfuric acid $\left(\mathrm{H}_{2} \mathrm{SO}_{4}\right)$, polysulfides of sulfur and hydrogen sulfite $[18,39,57]$. A field study investigating the efficacy of $\mathrm{CaSO}_{4} \cdot 2 \mathrm{H}_{2} \mathrm{O}$ and polysulfides on a saline soil has shown that gypsum is the most effective amendment in soil reclamation [39]. When applied to saline soils, gypsum can improve the soil's physical (bulk density, aggregate stability and water infiltration) and chemical ( $\mathrm{pH}, \mathrm{SAR}, \mathrm{ESP}, \mathrm{CEC}, \mathrm{EC}$, nutrients availability and organic carbon) characteristics, as well as biomass and crops production [39,58-60]. Gypsum application increases the availability of several nutrients, such as $\mathrm{P}$, and promotes a balanced concentration of electrolytes in the soil solution $[59,60]$. Besides the physical and chemical properties of soil, gypsum application also stimulates increased soil microbial activity, biomass and respiration [60].

\subsection{Mechanisms of Gypsum Efficacy in Saline Soils}

One of the most important factors of gypsum in the amelioration of soil salinity is that it is cheap and easy to use [24,39]. Gypsum can be mined from sedimentary rocks that have formed in the marine environment with high $S$ and Ca deposits. Gypsum can also be formed as a by-product in the industrial production of sulfuric and phosphoric (phosphogypsum) acids and in flue gas desulfurization [61]. In calcareous soils, which contain an adequate amount of calcium carbonate $\left(\mathrm{CaCO}_{3}\right)$, gypsum could easily be formed by the addition of elemental S [62]. The application of $S$ reduces a plant's uptake of toxic elements and improves salt-affected soils' productivity [11]. Since soil salinity increases the soil $\mathrm{pH}$, the use of chemical amendments to lower the soil $\mathrm{pH}$ would be highly desirable in reclaiming such soils. In line with this, $\mathrm{S}$ contained in gypsum is an acid former that allows decreasing the $\mathrm{pH}$ and electrical conductivity (EC) of the soil in a fast way under humidity conditions and favorable temperatures [63]. Thus, the major effects of gypsum on high $\mathrm{pH}$, calcareous saline soils are enhanced through the presence of $S$, which rapidly acidifies the soil as it oxidizes to a strong acid (e.g., $\mathrm{H}_{2} \mathrm{SO}_{4}$ ) that does lower the soil pH [22]. However, if $\mathrm{S}$ is applied as elemental $\mathrm{S}$ instead of gypsum, the newly formed $\mathrm{H}_{2} \mathrm{SO}_{4}$ may 
further react with carbonates and bicarbonates in the soil to become leachable $\mathrm{Na}_{2} \mathrm{SO}_{4}$ [64]. In the elemental form, an excess amount of $S$ goes into the reaction in the soil water and may be easily lost from the rhizosphere. However, in the form of gypsum, the amount of $S$ that goes into the reaction is regulated by the bonds between $\mathrm{Ca}$ and $\mathrm{S}$ amidst the water molecules. More discussions on the importance and regulatory roles of $S$ in plants response to salinity stress is provided in Section 3.2 below.

Another importance of gypsum application in saline soils is its provision of $\mathrm{Ca}$. In saline soils, a substantial percentage of the exchangeable $\mathrm{Na}^{+}$needs to be removed by $\mathrm{Ca}^{2+}$, and this reaction can be rapidly accomplished using $\mathrm{CaSO}_{4} \cdot 2 \mathrm{H}_{2} \mathrm{O}$. Scientific investigations have demonstrated that the use of $\mathrm{CaSO}_{4} \cdot 2 \mathrm{H}_{2} \mathrm{O}$ reduces $\mathrm{Na}^{+}$from the cations exchange sites, thereby reducing its uptake by plants $[24,65]$. This exchange of $\mathrm{Ca}^{2+}$ for $\mathrm{Na}^{+}$in the soil colloids improves soil stabilization and permeability (Equation (1)). However, upon the application of gypsum, it must be well-mixed with the soil followed by adequate water application to take out the displaced $\mathrm{Na}^{+}$from the rhizosphere. An increase in $\mathrm{Ca}^{2+}-\mathrm{to}_{-} \mathrm{Na}^{+}$ ratios on clay surfaces prevent soil dispersion and promote a stable soil structure, as well as an increased clay flocculation [66]. This also makes more $\mathrm{Ca}^{+}$available for plant uptake (Figure 2). On uptake at moderate levels, Ca supplementation promotes crops tolerance to salinity stress by increasing the hydraulic conductivity and leaf surface area [67]. Intracellularly, $\mathrm{Ca}^{2+}$ helps the activation of salt signaling pathways, such as the SOS pathway that allows plants to evolve a quick response against salt stress [12,13]. An adequate nourishment of $\mathrm{Ca}^{2+}$ helps maintain cell membrane integrity and selectivity, thereby preventing excessive accumulation of $\mathrm{Na}^{+}$and $\mathrm{Cl}^{-}$[68]. Importantly, $\mathrm{Ca}^{2+}$ modulation of the proteins involved in $\mathrm{K}^{+}$and $\mathrm{Na}^{+}$transport favors the mobilization of $\mathrm{K}^{+}$against the influx of $\mathrm{Na}^{+}$, thereby increasing the $\mathrm{K}^{+} / \mathrm{Na}^{+}$ratio in salinity-stressed plants [13]. Provision of $\mathrm{Ca}$ through gypsum application can also help with reversing the negative impact of salinity on P uptake [23].

$$
\text { Soil colloids }-\mathrm{Na}^{+}+\mathrm{CaSO}_{4} \cdot 2 \mathrm{H}_{2} \mathrm{O}=\text { Soil colloids }-\mathrm{Ca}^{2+}+\mathrm{Na}_{2} \mathrm{SO}_{4}+2 \mathrm{H}_{2} \mathrm{O}
$$

Apart from the cost and management problems associated with the use of leaching in managing saline soils, its effectiveness is also hindered by poor soil structure in sodic, saline-, alkaline- and acidic-sodic soils [10]. However, the application of gypsum to improve the soil structure before leaching is more effective in the management of saline soils for glycophytes production [10]. In addition to leaching with a non-saline water, gypsum application acidifies salt-affected soils to promote higher water uptake and improved soil physicochemical properties [18]. The application of $\mathrm{CaSO}_{4} \cdot 2 \mathrm{H}_{2} \mathrm{O}$ reduced the soil $\mathrm{pH}$ from 8.18 to 7.64 , soil EC from 6.21 to $2.39 \mathrm{dS} \mathrm{m}^{-1}$, SAR from 42.39 to $9.39\left(\mathrm{mmol}_{\mathrm{C}} \mathrm{L}^{-1}\right)^{1 / 2}$ and ESP from $39.54 \%$ to $10.56 \%$ [39]. Other studies have also reported similar results using gypsum [11,18,20,24,60]. Gypsum reportedly reduced both SAR and ESP by 11-folds each compared to control treatments that had no gypsum application [60]. In saline sodic soils, gypsum reduces soil crusting, thereby enhancing water infiltration and deep rooting of crops in the soil [61]. After three years of gypsum application (5 $\left.\mathrm{tha}^{-1}\right)$, the EC of a salinesodic soil was reduced by $9 \%, 46.5 \%, 91.3 \%, 123 \%$ and $174 \%$ at soil depths of $0-20 \mathrm{~cm}$, 20-40 cm, 40-60 cm, 60-80 cm and 80-100 cm, respectively, compared to plots that had no gypsum application [69]. Similarly, a field study has demonstrated that gypsum application on a sodic soil helped in the reclamation of the soil by reducing spontaneous dispersion and the ESP by $26 \%$ up to a depth of $0.5 \mathrm{~m}$ over a period of about 3.5 years [70]. 


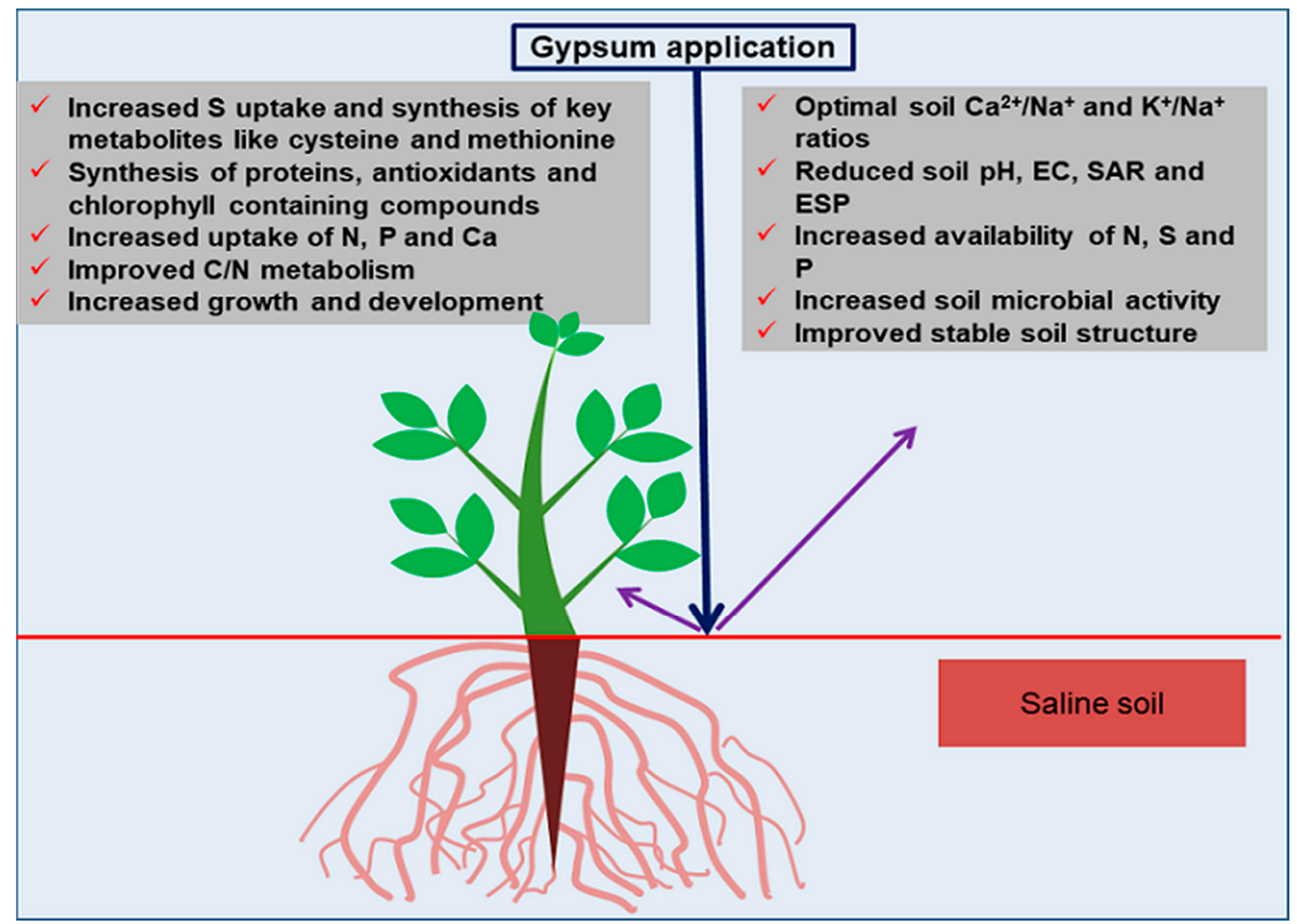

Figure 2. An illustration of the effects of gypsum at the soil-plant interface of a saline soil.

Due to the foregoing attributes of gypsum, different studies have demonstrated the potential of gypsum and associated S-containing compounds to improve the growth of many crops, including cabbage [71], barley [17], maize [72] and tomato [73] grown under salinity stress conditions (Table 1). Nevertheless, gypsum needs to be applied in large quantities to be highly effective in reclaiming saline soils [56,74]. The actual amount of the gypsum required to reclaim a particular saline soil can be calculated using the soil gypsum requirement (Alcívar et al., 2018). The gypsum requirement can be calculated as shown in Equation (2) below. Gypsum also has a low solubility $\left(2.1 \mathrm{~kg} \mathrm{~m}^{-3}\right.$ or $\left.2 \mathrm{~g} \mathrm{~L}^{-1}\right)$ and requires adequate water to dissolve its chemical components into $\mathrm{Ca}$ and $\mathrm{SO}_{4}$ to enhance its effectiveness in reclaiming saline soils $[10,75]$.

$$
\text { Gypsum requirement }=\frac{\text { ESPini }- \text { ESPdes }}{100} * \mathrm{CEC} * 1.72 \text { ton }
$$

where ESPini is the initial ESP (\%) of the soil to be amended; ESPdes is the desired ESP (\%); CEC is the cation exchange capacity of the soil in meq100 g $\mathrm{g}^{-1}$ soil; 1.72 ton is the amount of $\mathrm{CaSO}_{4} \cdot 2 \mathrm{H}_{2} \mathrm{O}$ required to reduce $\mathrm{Na}^{+}$content of the soil by one unit (1 meq Na $100 \mathrm{~g}^{-1}$ soil)

\subsection{Regulatory Roles of Sulfur in Plants under Salinity Stress}

On the terrestrial biosphere, $\mathrm{S}$ is found as sulfide $\left(\mathrm{S}^{-2}\right)$ minerals, such as pyrite, or sulfate minerals, such as gypsum [76]. Sulfur is the fourth most essential macronutrient for plant growth and development after $\mathrm{N}, \mathrm{P}$ and $\mathrm{K}$, but it is commonly deficient on agricultural fields [77]. One of the remarkable impacts of $S$ in the mineral nutrition of plants is its importance in the adaptation of plants to salinity stress conditions [71,78]. Sulfur serves regulatory and catalytic functions in the plant cells, and it is taken up in its inorganic form as sulfate- $\mathrm{SO}_{4}{ }^{2-}[79,80]$. Sulfate can be absorbed from the soil and translocated within the plants through the activity of sulfate transporters (SULTRs) in the 
root or directly assimilated from the shoots and leaves if naturally or anthropogenically available sulfur dioxide $\left(\mathrm{SO}_{2}\right)$ or hydrogen sulfide $\left(\mathrm{H}_{2} \mathrm{~S}\right)$ are in the atmosphere $[21,81,82]$.

Stress regulatory mechanisms in plants are structured to utilize $S$ in the alleviation of plant stress $[21,83]$. S is an integral part of the thioredoxin system, which regulates physiological processes and raises salt tolerance [84]. A critical concentration of $S$ in plant tissues regulates chlorophyll content, $\mathrm{C} / \mathrm{N}$ metabolism, activity of photosynthetic enzymes, protein synthesis and the electron transport system $[21,51,85]$. Plant photosynthesis in salt-stressed conditions is potentially regulated by the availability of $S$, which counters salt-induced oxidative stress $[86,87]$. This is achieved by being a major component of the ferredoxin (Fe-S protein) complex that transports free electron in the cells [88]. Sulfur and its derivatives (e.g., glutathione) improve the antioxidant-defense pathway by maintaining a reduced cellular-redox condition and scavenging excessive reactive oxygen species (ROS) under different abiotic stresses, especially, salinity $[77,89,90]$. ROS, including hydrogen peroxide, hydroxyl and superoxide radicals, impose oxidative stress, membrane instability and unbalanced nutrient homeostasis on plants [91]. Thus, sulfate deficiency in plants often results in reduced plant resistance and vigor against biotic and abiotic stresses, as well as stunted plant growth and development [76,92].

Sulfate is utilized by plants for the biosynthesis of different metabolites, such as methionine and cystein [21,93]. Cysteine, a major part of plants thiol-peptide responsible for the primary metabolism, mediates the secretion of thionins, elemental S, phytochelatins, sulfolipids, S-rich proteins, coenzyme A, metallothioneins, $\mathrm{H}_{2} \mathrm{~S}$ and glutathione in response to environmental cues, such as salinity stress and $S$ deficiency $[21,51,80,93]$. Therefore, plants with low ATP-sulfurylase (adenosine5'-triphosphate sulfurylase), the enzyme catalyzing the reduction of $\mathrm{SO}_{4}{ }^{2-}$ to $\mathrm{S}_{2}$ in the cells before incorporation into cysteine, activity are mostly salt-sensitive $[21,78,93,94]$. Sulfur interacts with different phytohormones, including auxin, gibberellin, cytokinin, abscisic acid, ethylene, jasmonic acid (JA) and salicylic acid (SA), under an abiotic stress condition to promote plant growth [84]. The assimilation of $\mathrm{SO}_{4}{ }^{2-}$ during salt stress revealed that adenosine $5^{\prime}$-phosphosulfate (APS) reductase activity is up-regulated by the exogenous application of ethylene precursor 1-aminocyclopropane carboxylate (ACC), which confers tolerance to salinity in Arabidopsis [95]. Transgenic approaches have been employed successfully to increase the capacity of salt tolerance in plants by manipulating $S$ assimilation and metabolism pathways [79].

The application of $S$ containing compounds increases the uptake and concentration of $\mathrm{Ca}^{2+}$ in the plant tissues with a decreasing $\mathrm{Na}^{+}$uptake $[20,39,60]$, as shown in Table 1 . It has been demonstrated that $\mathrm{S}$ applied as $\mathrm{H}_{2} \mathrm{~S}$ increases the growth of crops under salt stress by maintaining physiological processes, such as ion homeostasis [17]. Further studies have also shown that $S$ supplementation improved the photosynthetic efficiency of plants under salt stress via increased glutathione production and enzymes activity [86,96]. Foliar application of S-containing compounds, such as $\mathrm{FeSO}_{4}$, thiourea and $\mathrm{LiSO}_{4}$, have also been reported to aid the tolerance of glycophytes, such as maize [97] and canola [98], to salt stress. However, despite the importance of $S$, it is worthy to note that an excess amount of $S$ compounds $\left(\mathrm{SO}_{4}{ }^{2-}, \mathrm{H}_{2} \mathrm{~S}, \mathrm{SO}_{2}\right.$, and $\mathrm{SO}_{3}{ }^{2-}$-sulfite) in the biosphere could be detrimental to plants, animals, humans and the environment in totality [99]. Additionally, the application of $S$ in excessive amounts beyond crop needs could result in increased soil salinity [22]. 
Table 1. The effects and rates of S-containing compounds in the amelioration of salinity stress on crops.

\begin{tabular}{|c|c|c|c|c|}
\hline S-Containing Compound & Optimal Application Rate & Crop & Impact on Soil and Crop Productivity & Reference \\
\hline Elemental S & $700 \mathrm{~kg} \mathrm{~S} \mathrm{ha}^{-1}$ & $\begin{array}{l}\text { Red Cabbage (Brassica } \\
\text { oleracea var. capitata L.) }\end{array}$ & $\begin{array}{l}\text { Increased head weight and total yield; } \\
\text { Increased } \mathrm{S}, \mathrm{P}, \mathrm{N} \text { and } \mathrm{K} \text { uptake; } \\
\text { Reduced leaf } \mathrm{Na}^{+} \text {content }\end{array}$ & [71] \\
\hline Elemental S & $1120 \mathrm{~kg} \mathrm{~S} \mathrm{ha}^{-1}$ & $\begin{array}{l}\text { Sugarcane (Saccharum sp. } \\
\text { var. CP87-3388) }\end{array}$ & $\begin{array}{l}\text { Increased available soil P and S; } \\
\text { Increased leaf area index }\end{array}$ & [22] \\
\hline Elemental S & $500 \mathrm{~kg} \mathrm{~S} \mathrm{ha}^{-1}$ & Pea (Pisum sativum L.) & $\begin{array}{l}\text { Increased growth and yield; Increased } \\
\text { uptake of } \mathrm{N}, \mathrm{P} \text { and K; Reduced leaf } \\
\qquad \mathrm{Na}^{+} \text {content }\end{array}$ & [100] \\
\hline Agricultural sulfur ( $98 \%$ S) & $600 \mathrm{~kg} \mathrm{~S} \mathrm{ha}^{-1}$ & $\begin{array}{c}\text { Rice (Oryza sativa L. cv. } \\
\text { Sakha 106) }\end{array}$ & $\begin{array}{l}\text { Decreased soil pH, EC and bulk } \\
\text { density; Increased growth and yield }\end{array}$ & [101] \\
\hline Gypsum & 5 tha $^{-1}$ & $\begin{array}{l}\text { Berseem clover (Trifolium } \\
\text { alexandrinum L. cv. Helaly) }\end{array}$ & $\begin{array}{l}\text { Decreased soil } \mathrm{pH} \text { and } \mathrm{EC} \text {; Increased } \\
\text { soil available K; Increased growth, } \\
\text { herbage production and forage quality }\end{array}$ & [102] \\
\hline Gypsum & $10.52 \mathrm{t} \mathrm{ha}^{-1}$ & $\begin{array}{l}\text { Fodder beet (Beta vulgaris } \\
\text { cv. Kawai terma) }\end{array}$ & $\begin{array}{l}\text { Decreased soil } \mathrm{pH}, \mathrm{SAR}, \mathrm{EC} \text { and bulk } \\
\text { density; increased root and shoot } \\
\text { biomass production }\end{array}$ & [103] \\
\hline Gypsum & $4 \mathrm{tha}^{-1}$ & $\begin{array}{l}\text { Onion (Allium cepa L. cv. } \\
\text { Adama red) }\end{array}$ & $\begin{array}{l}\text { Decreased soil EC and ESP; increased } \\
\text { exchangeable } \mathrm{Ca}^{2+} \text { and onion yield }\end{array}$ & [104] \\
\hline Gypsum & $12 \mathrm{t} \mathrm{ha}^{-1}$ & Grapevine (Vitis vinifera) & $\begin{array}{l}\text { Decreased soil ESP, improved root } \\
\text { growth, water penetration and fruit } \\
\text { yield. }\end{array}$ & [70] \\
\hline Gypsum & $9.2 \mathrm{tha}^{-1}$ & $\begin{array}{l}\text { Wheat (Triticum aestivum L. } \\
\text { cv. Gemmeiza 11) }\end{array}$ & $\begin{array}{l}\text { Increased grain yield and reduced soil } \\
\text { and irrigation water salinity }\end{array}$ & [66] \\
\hline
\end{tabular}

\section{Emerging Perspectives in the Amelioration of Salt-Affected Soils}

Apart from the use of soil amendments in saline soils reclamation, the choice of crop to be cultivated is also very important. Several studies have proven that the use of halophyte species in agriculture may facilitate crop adaptation to increased salinization while contributing to the improvement of soil quality and food security $[10,105]$. Some economically important halophytes are sorghum, rye, date palm, grape, guava, mango, olive, oilseed rape, guar, cotton, artichoke, kenaf, mustard and some varieties of wheat and barley $[6,50,86,106-109]$. Other species of halophytes, including quinoa, seaside purslane, pearl millet, saltwort, eelgrass and sea fennel, have been identified for their use as vegetables and traditional foods in different parts of the world [110]. Since halophytes can remove a lot of salt from the environment, it makes it possible for the cultivation of glycophytes in the same soil after few seasons of halophytes cultivation. Furthermore, the cultivation of halophytes with gypsum application is a viable practice to improve plant growth and production on salt-affected soils. Gypsum applied, along with the planting of Atriplex amnicola, Atriplex halimus and Atriplex lentiformis, has been shown to greatly reduce the soil salinity level, ESP and SAR of a saline-sodic soil [20]. Chlorosis guayana and Cynodon dactylon cultivation with gypsum application in a saline-sodic soil improved the soil $\mathrm{pH}, \mathrm{SAR}, \mathrm{ESP}, \mathrm{EC}$ and water infiltration [111]. Likewise, the application of gypsum resulted in higher biomass yield and the accumulation of $\mathrm{Na}^{+}$in the aerial parts of Sesuvium verrucosum due to the soil improved physicochemical properties [39].

Another viable practice in the management of saline soils is the integrated application of gypsum and elemental S. The combined application of gypsum and elemental S increases the efficacy of gypsum in the amelioration of saline soils, especially in saline-sodic soils. In saline-sodic soils, the sole application of $\mathrm{CaSO}_{4} \cdot 2 \mathrm{H}_{2} \mathrm{O}$ may result in the precipitation of $\mathrm{CaCO}_{3}$ due to a high level of alkalinity $(\mathrm{pH})$ [74]. If $\mathrm{CaCO}_{3}$ precipitates, $\mathrm{Ca}^{2+}$ availability on the exchange sites or soil solution and uptake by plants would be constrained. In this case, the addition of elemental $\mathrm{S}$ neutralizes the alkalinity and solubilizes $\mathrm{CaCO}_{3}$ to release $\mathrm{Ca}^{2+}$ through its oxidation to sulfuric acid. Hence, it has been shown that the mixture of gypsum and elemental $\mathrm{S}$ reduces the precipitation of $\mathrm{CaCO}_{3}, \mathrm{SAR}$ and soil $\mathrm{pH}$ to cause an improved plant growth and yield on a saline-sodic soil [74]. Furthermore, it has been demonstrated that the integrated use of gypsum, elemental $\mathrm{S}$ and compost improved the quality and productivity of berseem clover cultivated on a saline soil by ameliorating 
salt-induced stress through changes in the soil properties [102]. Thus, there is a need for more investigations on other inputs that could increase the efficiency of gypsum in ameliorating saline soils.

\subsection{Effects of Bio-Organic Amendments on Saline Soils}

The amelioration of salt-affected soils is dependent on the type of salinity and availability of soil amendments that could counter the effect of salinity on soils. $\mathrm{CaSO}_{4} \cdot 2 \mathrm{H}_{2} \mathrm{O}$ and bio-organic amendments are among soil inputs that have been continuously recognized to improve the biological, physical and chemical properties of saline soils for increased food production. Bio-organic amendment is a term used to indicate the integrated use of beneficial microbes and organic sources of nutrients in the cultivation of crops for an increased yield. Bio-organic amendments have a high potential to improve both soil and crop productivity through increased soil organic matter, essential nutrients (especially, $\mathrm{N}$ and $P$ ) and water availability, stable soil structure and increased microbial activity [112]. The beneficial microbes may include plant growth-promoting (PGP) microorganisms, arbuscular mycorrhizal fungi (AMF), cellulose-decomposing bacteria, P-solubilizing bacteria and $\mathrm{N}$-fixing bacteria. The use of beneficial microbes or plant growth-promoting microorganisms or biofertilizers is an important strategy that improves the tolerance of crops to saline soil conditions $[6,31,113]$. It has been suggested that the exploitation of microbes ecological survival characteristics, such as salinity tolerance through the synthesis of plant growth promoting hormones, compatible solutes (e.g., glycine betaine) that counteract the effect of salts and their inherent genetic diversity, could help in improving crops tolerance to salinity stress [31]. Generally, plant root-colonizing microorganisms (e.g., fungi and bacteria) form symbiotic associations with plants to confer tolerance under different stress conditions, such as salinity. This is achieved by improving the root system development for an increased uptake of water, essential nutrients and other organic compounds to counteract the negative impact of $\mathrm{Na}^{+}$in the rhizosphere. The dual inoculation of AMF (Rhizophagus intraradices) and PGP bacteria (Massilia sp. RK4) has been demonstrated to promote salt tolerance in maize by increasing nutrient accumulation, AMF colonization and leaf proline production [114].

Soil microbes play a significant role in nutrient cycling through mineralization and immobilization and thus have positive effects on soil nutrient availability, aeration and organic matter [115]. Investigations on Pseudomonas stutzeri and Trichoderma harzianum have shown their potential for enhancing glycophytes tolerance to salinity stress $[113,116]$. For instance, it has been demonstrated that Trichoderma harzianum potentially improves the yield of tomato, as well as soil fertility and biodiversity under salinity stress conditions [117]. Trichoderma harzianum inoculation reduces SAR and increases tomato fruit yield and the available soil $\mathrm{P}$ level in a saline soil condition [118]. In a saline water irrigation (3000 ppm) imposed salinity experiment, the individual application of Azospirillum, peanut compost and their combination (Azospirillum-compost) caused a significant increase in germanium plant growth and biomass yield with reduced $\mathrm{Na}^{+}$accumulation [119]. The inoculation of Bacillus pumilus and Pseudomonas pseudoalcaligenes improves rice (GJ17, a saltsensitive cultivar) tolerance to salinity stress by enhancing a reduction in the toxicity of ROS, superoxide dismutase activity and lipid peroxidation [120]. Other microbial mechanisms that enhance crop tolerance to salinity stress include increased 1-aminocyclopropane-1carboxylate deaminase, nitrate reductase and nitrogenase activities, the regulation of leave water content, phosphate solubilization, higher $\mathrm{K}^{+} / \mathrm{Na}^{+}$ratio, improved germination and growth, indole acetic acid and exopolysaccharide production, as well as the regulation of $\mathrm{Na}^{+}$transporter (HKT1) and reduced production of ethylene [31].

Organic materials may include compost, straw, organic manure, green manure, humic substances and biochar. The addition of these organic materials to saline soils may improve soil quality and health for increased crop production. The breakdown of organic amendments in the soil gives off $\mathrm{CO}_{2}$ and hydrogen ion $\left(\mathrm{H}^{+}\right)$, as well as organic acids [104]. The $\mathrm{CO}_{2}$ is incorporated into the soil as soil organic carbon (C) during the decomposi- 
tion of added organic materials by soil microbes [121,122]. $\mathrm{CO}_{2}$ fixation by plants during photosynthesis also adds to the pool of soil organic carbon after plant leaves and roots decompose in the rhizosphere [122]. The released $\mathrm{H}^{+}$from the breakdown of organic materials goes off into reaction with the salts and carbonates to solubilize them into their component parts. For example, $\mathrm{CaCO}_{3}$ in calcareous soils is solubilized to release $\mathrm{Ca}$ for plant uptake and $\mathrm{CO}_{2}$ for further incorporation as soil organic carbon. The released organic acids also aid the mineralization of more organic mineral component of the soil. In a saline soil $\left(10.6 \mathrm{dS} \mathrm{m}^{-1}\right)$ irrigated with a slightly saline water $\left(4.28 \mathrm{dS} \mathrm{m}^{-1}\right)$, organic amendments, including vermicompost and cow dung, were found to improve the soil EC $\left(3.37 \mathrm{dS} \mathrm{m}^{-1}\right)$ and $\mathrm{pH}$, thus increasing maize growth compared to untreated control [123]. The application of organic materials in the topsoil of saline soils help in reducing soil evaporation, salt water movement and salt accumulation by regulating the distribution of salt in the rhizosphere [23]. In terms of plant responses to the salinity stress condition, the addition of organic matter potentially reduces the uptake of $\mathrm{Na}^{+}$with the consequent increase in essential nutrients uptake to enhance improved growth. The use of organic amendments on saline soils also improves porosity, hydraulic conductivity, soil aggregate stability and permeability [124]. Organic matter acts as chelates for basic cations, such as $\mathrm{Ca}^{2+}$ and $\mathrm{Mg}^{2+}$, in the soil solution and thus promotes their uptake compared to $\mathrm{Na}^{+}$ and also reduces SAR. Similar to gypsum application, wheat straw application containing approximately $0.75 \mathrm{t} \mathrm{ha}^{-1}$ of each of $\mathrm{Ca}^{2+}$ and $\mathrm{Mg}^{2+}$ contributed an adequate amount of these cations in the soil solution and thus makes them available for plant uptake [70]. In addition, organic manure incorporation into saline-water-irrigated soil improves the soil available $\mathrm{N}$ and $\mathrm{K}$ and their consequent uptake by tomato plants [125].

\subsection{Complementary Use of Gypsum and Bio-Organic Amendments in the Management of Saline Soils}

Due to the great impact of beneficial microbes and organic materials in soil fertility improvement, their integration with gypsum application has the potential to have a remarkable effect on the amelioration of saline soils (Figure 3). In a soil column investigation, gypsum application in conjunction with compost (rice straw and hyacinth) reportedly reduced the salinity and sodicity levels of a saline-sodic soil more efficiently than the control or the use of either gypsum or the composts alone [126]. The integrated application of gypsum with compost has been reported to produce the highest yield of onion in a saline-sodic soil by causing a reduction in EC, ESP, pH and SAR [104]. The addition of compost improves the soil organic carbon sequestration potential, CEC and availability of nutrients, which are mostly deficient in saline soils, and thus enhances the effectiveness of gypsum to reduce the soil EC, SAR, ESP and $\mathrm{pH}$. Gypsum application, along with humic acid and organic manure, in a saline-sodic soil has been demonstrated to improve soil $\mathrm{pH}, \mathrm{SAR}, \mathrm{EC}\left(2.65 \mathrm{dS} \mathrm{m}^{-1}\right.$ from $\left.6.35 \mathrm{dS} \mathrm{m}^{-1}\right)$ and, consequently, the root growth and yield of rice [127]. Another investigation has demonstrated that three years after organic matter addition with gypsum application, there was a reduction in clay dispersion and an increase in exchangeable $\mathrm{Ca}^{2+}$ in the subsoil [128]. Similarly, the application of gypsum and farmyard manure have been reported to have improved soil properties, including $\mathrm{pH}$, bulk density, EC, organic matter, hydraulic conductivity and SAR, after 3 years of application on a saline-sodic soil field condition [103]. 


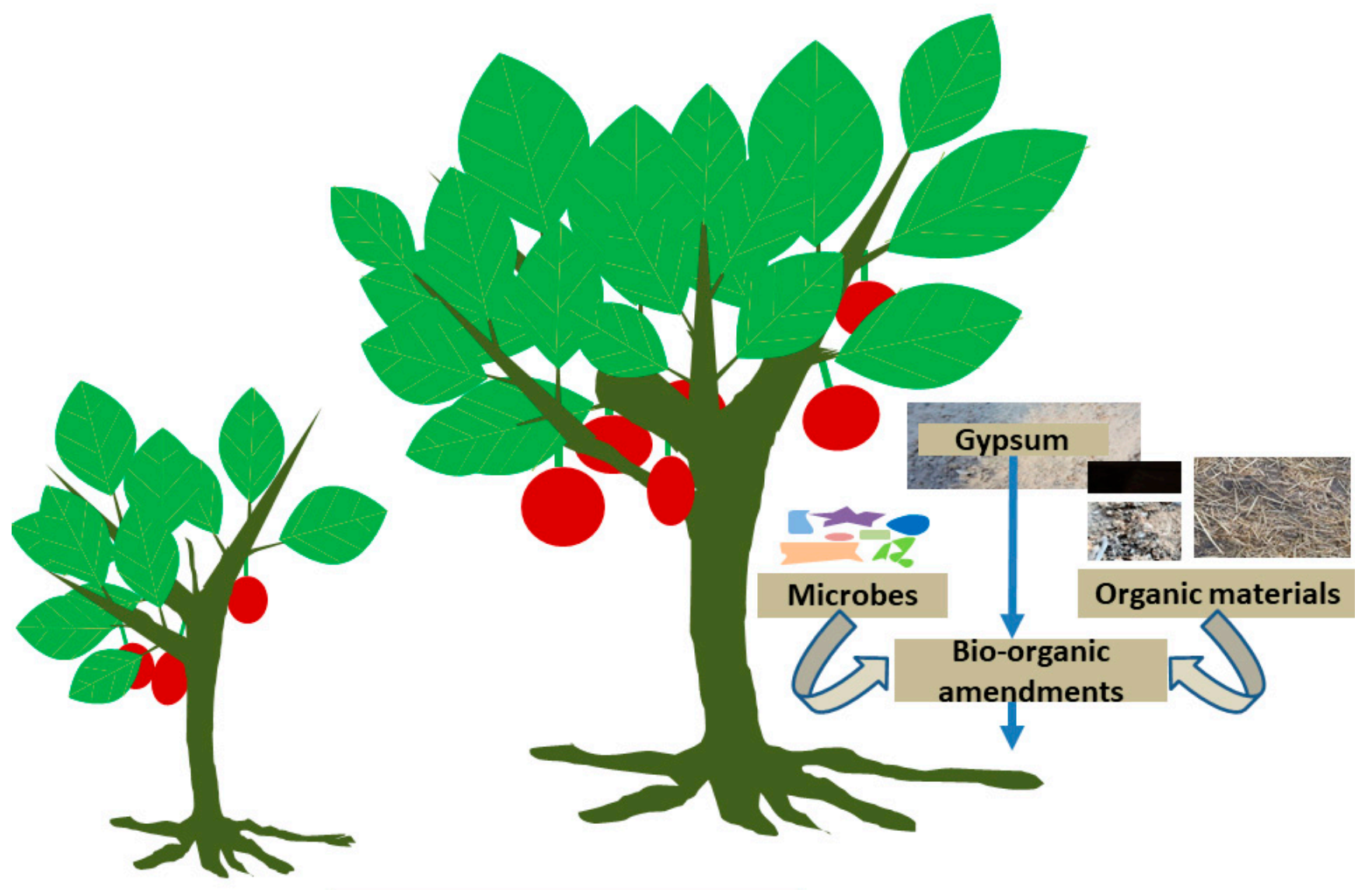

\section{Saline soil}

Figure 3. A hypothetical diagram depicting the potential influence of the integrated use of gypsum and bio-organic amendments on crop production.

The inoculation of beneficial microbes in conjunction with gypsum application has been demonstrated to improve the solubility of gypsum for higher efficiency in ameliorating saline soils [129]. It has been reported that the combination of gypsum with Acidithiobacillus thiooxidans and Bradyrhizobium spp inoculation improved the growth of cowpea by making more nutrients (P and K) available for uptake on a saline-sodic soil [56]. Likewise, a saline-sodic soil ameliorated with gypsum in conjunction with two bacterial (Bacillus megaterium and Bacillus subtilis) and two fungal species (Alternaria spp. and Aspergillus spp.) was found to have improved soil saturated hydraulic conductivity, which causes easy water movement for plant use [129]. Furthermore, S-incorporated citrus wood biochar, in combination with a consortium of plant growth-promoting microorganisms, was found to improve the growth, quality and yield of Capsicum annum (pepper) on saline soil through reduced Na uptake and increased N, P, K, Ca, Fe and Mn uptake [91]. The consortium of the beneficial microorganisms included Streptomyces griseus, Streptomyces albus, Candida utilis, Saccharomyces cerevisiae, Streptoccus lactis, Lactobacillus plantarum, Rhodobacter spaeroides, Rhodopseudomonas palustrus, Mucor hiemalis, Aspergillus oryzae and Penicillium sp. [91]. Furthermore, gypsum application, in conjunction with biochar and compost tea (containing organic matter and beneficial microbes), has also been shown to ameliorate the effect of soil salinity on wheat production by reducing the SAR, EC and ESP [130]. Despite the potential importance of the integrated use of gypsum and bio-organic amendments in the reclamation of salt-affected soils, only a few standard studies have been conducted in this regard at the field level (Supplementary Table S1). More studies exploring the integrated use of gypsum, organic matter and beneficial plant growth-promoting microbes in 
alleviating soil salinity stress on agricultural productions would be beneficial for improving the global food security.

\section{Conclusions}

Globally, a substantial percentage of soils that are cultivated for agricultural production are constrained by salinity and are more prevalent in the arid to the semiarid regions compared to the humid and temperate regions of the world. Notwithstanding, this percentage is a small fraction of the total global land area that are salt-affected and could be potentially reclaimed for agricultural productions. Thus, the attainment of an increased global food security calls for continued research efforts aimed at alleviating salt stress on crops in saline soils. In this regard, the use of gypsum and bio-organic amendments in salt-affected soils has been identified among sustainable means for alleviating the effect of salt stress on soil quality and productivity, as well as optimal crop growth and yields. Gypsum and bio-organic amendments nourish crops with the required essential nutrients (N, P, K, Ca, Mg and S) and improves the overall physical, chemical and biological properties of saline soils, including $\mathrm{pH}, \mathrm{EC}, \mathrm{SAR}, \mathrm{EC}, \mathrm{CEC}$, organic matter, nutrient cycling, porosity, water-holding capacity, enzyme activities, microbial biomass and biodiversity. Particularly, the provision of $S$ through the gypsum application increases crops' tolerance to salinity stress by regulating various biochemical and physiological processes, such as the $\mathrm{Na}^{+}$balance, water status, reactive oxygen species, photosynthesis and phytohormone levels. Sulfur also stimulates a crop's response to salt stress by inducing the biosynthesis, transport and secretion of proteins, antioxidants and polyamines, as well as up-regulating genes that are highly functional in alleviating various abiotic stresses. Ca provision through gypsum application is also very important at the soil-plant interface to aid crops tolerance to salinity stress as it prevents the uptake $\mathrm{Na}^{+}$from the soil solution.

For gypsum to be highly effective in saline soil amelioration, adequate water must be available to irrigate the soil after gypsum application to enhance the quick leaching out of displaced $\mathrm{Na}^{+}$from the rhizosphere. Additionally, in addressing soil salinity problems either with the individual or combined use of gypsum and bio-organic amendments, adequate attention should be paid to the quality of water used in irrigating crops to ensure that they do not contain ions that could aggravate soil salinity. In addition, it is noteworthy to mention that, despite the efficiency of gypsum in reclaiming salt-affected soils, its efficacy on a field-scale may not be obvious or optimally available in the first year of application but rather not until an average of three years after application. Thus, it is hypothesized that the use of bio-organic amendments, which improve the soil organic matter, microbial population and activities, in conjunction with gypsum could potentially help in attaining an appreciable result in the first year of application and beyond. Likewise, chemical fertilizer and pesticide applications should be substituted or complemented with bio-organic inputs to reduce the increasing salinization of arable lands. Finally, the reclamation of saline soils using gypsum and bio-organic amendments to sequester $\mathrm{C}$ into the soil as organic $\mathrm{C}$ would add to the pool of efforts aimed at mitigating global climate changes by reducing the amount of $\mathrm{CO}_{2}$ in the atmosphere while increasing global food security. Thus, this review recommends that more scientific investigations at field, greenhouse and laboratory levels should be conducted to explore the use of integrated gypsum and bio-organic amendments in the reclamation of saline soils.

Supplementary Materials: The following are available online at https:/ / www.mdpi.com/article/10 .3390/agronomy11091735/s1, Table S1: A list of studies that used combined gypsum and bio- and/or organic amendments in mitigating salinity stress.

Author Contributions: Writing-original draft preparation, S.K.B.; writing-review and editing, S.K.B., A.H.A., S.G.A.-S. and K.A.M.A.-E.; funding acquisition, A.H.A. and S.G.A.-S. All authors have read and agreed to the published version of the manuscript.

Funding: This research received no external funding. 
Institutional Review Board Statement: Not applicable.

Informed Consent Statement: Not applicable.

Conflicts of Interest: The authors declare no conflict of interest.

\section{References}

1. Young, J.; Udeigwe, T.K.; Weindorf, D.C.; Kandakji, T.; Gautam, P.; Mahmoud, M.A. Evaluating management-induced soil salinization in golf courses in semi-arid landscapes. Solid Earth 2015, 6, 393-402. [CrossRef]

2. Akram, S.; Siddiqui, M.N.; Hussain, B.M.N.; Al Bari, M.A.; Mostofa, M.G.; Hossain, M.A.; Tran, L.-S.P. Exogenous glutathione modulates salinity tolerance of soybean [Glycine max (L.) Merrill] at reproductive stage. J. Plant Growth Regul. 2017, 36, 877-888. [CrossRef]

3. Shahid, A.S.; Zaman, M.; Heng, L. Soil salinity: Historical perspectives and a world overview of the problem. In Guideline for Salinity Assessment, Mitigation and Adaptation Using Nuclear and Related Techniques; Springer: Berlin/Heidelberg, Germany, 2018; pp. 43-53.

4. Ahmad, P.; Ahanger, M.A.; Alam, P.; Alyemeni, M.N.; Wijaya, L.; Ali, S.; Ashraf, M. Silicon (Si) supplementation alleviates NaCl toxicity in mung bean [Vigna radiata (L.) Wilczek] through the modifications of physio-biochemical attributes and key antioxidant enzymes. J. Plant Growth Regul. 2018, 38, 70-82. [CrossRef]

5. Almeida, M.D.; Oliveira, M.M.; Saibo, N.J.M. Regulation of $\mathrm{Na}^{+}$and $\mathrm{K}^{+}$homeostasis in plants: Towards improved salt stress tolerance in crop plants. Genet. Mol. Biol. 2017, 40 (Suppl. S1), 326-345. [CrossRef] [PubMed]

6. Murphy, B.R.; Jadwiszczak, M.J.; Soldi, E.; Hodkinson, T.R. Endophytes from the crop wild relative Hordeum secalinum L. improve agronomic traits in unstressed and salt stressed barley. Cogent Food Agric. 2018, 4, 1549195. [CrossRef]

7. Wani, S.H.; Kumar, V.; Khare, T.; Guddimalli, R.; Parveda, M.; Solymosi, K.; Suprasanna, P.; Kavi Kishor, P.B. Engineering salinity tolerance in plants: Progress and prospects. Planta 2020, 251, 76. [CrossRef] [PubMed]

8. Kumar, A.; Kumar, A.; Kumar, P.; Lata, C.; Kumar, S. Effect of individual and interactive alkalinity and salinity on physiological, biochemical and nutritional traits of Marvel grass. Indian J. Exp. Biol. 2018, 56, 573-581.

9. Pitman, M.G.; Läuchli, A. Global impact of salinity and agricultural ecosystems. In Salinity: Environment-Plants-Molecules; Läuchli, A., Lüttge, U., Eds.; Springer: Dordrecht, The Netherlands, 2002.

10. Rengasamy, P. Soil processes affecting crop production in salt-affected soils. Funct. Plant Biol. 2010, 37, 613-620. [CrossRef]

11. Ahmed, K.; Qadir, G.; Jami, A.R.; Saqib, A.I.; Nawaz, M.Q.; Kamal, M.A.; Haq, E. Strategies for Soil Amelioration Using Sulphur in Salt Affected Soils. Cercet. Agron. Mold. 2016, 49, 5-16. [CrossRef]

12. Al-shareef, O.N.; Tester, M. Plant salinity tolerance. In eLS; John Wiley \& Sons Ltd.: Chichester, UK, 2019; pp. 1-6.

13. Zhu, J.-K. Plant salt stress. In eLS; John Wiley \& Sons Ltd.: Chichester, UK, 2007.

14. Wu, H.J.; Zhang, Z.; Wang, J.Y.; Oh, D.H.; Dassanayake, M.; Liu, B.; Huang, Q.; Sun, H.X.; Xia, R.; Wu, Y.; et al. Insights into salt tolerance from the genome of Thellungiella salsuginea. Proc. Natl. Acad. Sci. USA 2012, 109, 12219-12224. [CrossRef]

15. Ahanger, M.A.; Alyemeni, M.N.; Wijaya, L.; Alamri, S.A.; Alam, P.; Ashraf, M.; Ahmad, P. Potential of exogenously sourced kinetin in protecting Solanum lycopersicum from $\mathrm{NaCl}$-induced oxidative stress through up-regulation of the antioxidant system, ascorbate-glutathione cycle and glyoxalase system. PLoS ONE 2018, 13, e0202175. [CrossRef]

16. Aldesuquy, H.; Baka, Z.; Mickky, B. Kinetin and spermine mediated induction of salt tolerance in wheat plants: Leaf area, photosynthesis and chloroplast ultrastructure of flag leaf at ear emergence. Egypt. J. Basic Appl. Sci. 2014, 1, 77-87. [CrossRef]

17. Chen, J.; Wang, W.H.; Wu, F.H.; He, E.M.; Liu, X.; Shangguan, Z.P.; Zheng, H.L. Hydrogen sulfide enhances salt tolerance through nitric oxide-mediated maintenance of ion homeostasis in barley seedling roots. Sci. Rep. 2015, 5, 12516. [CrossRef] [PubMed]

18. Abdelhamid, M.; Eldardiry, E.; El-Hady, M.A. Ameliorate salinity effect through sulphur application and its effect on some soil and plant characters under different water quantities. Agric. Sci. 2013, 4, 39-47. [CrossRef]

19. Assaha, D.V.M.; Ueda, A.; Saneoka, H.; Al-Yahyai, R.; Yaish, M.W. The role of $\mathrm{Na}^{+}$and $\mathrm{K}^{+}$transporters in salt stress adaptation in glycophytes. Front. Physiol. 2017, 8, 509. [CrossRef]

20. Abdel-Fattah, M.K. Potential use of halophytes in combination with gypsum to reclaim and restore saline-sodic soils in Egypt. Malays. J. Soil Sci. 2015, 19, 131-139.

21. Capaldi, F.R.; Gratão, P.L.; Reis, A.R.; Lima, L.W.; Azevedo, R.A. Sulfur metabolism and stress defense responses in plants. Trop. Plant Biol. 2015, 8, 60-73. [CrossRef]

22. Wiedenfeld, B. Sulfur application effects on soil properties in calcareous soil and on sugarcane growth and yield. J. Plant Nutr. 2011, 34, 1003-1013. [CrossRef]

23. Cuevas, J.; Daliakopoulos, I.N.; del Moral, F.; Hueso, J.J.; Tsanis, I.K. A review of soil-improving cropping systems for soil salinization. Agronomy 2019, 9, 295. [CrossRef]

24. Gonçalo Filho, F.; da Silva Dias, N.; Suddarth, S.R.P.; Ferreira, J.F.S.; Anderson, R.G.; dos Santos Fernandes, C.; de Lira, R.B.; Neto, M.F.; Cosme, C.R. Reclaiming tropical saline-sodic soils with gypsum and cow manure. Water 2019, 12, 57. [CrossRef]

25. Nan, J.; Chen, X.; Chen, C.; Lashari, M.S.; Deng, J.; Du, Z. Impact of flue gas desulfurization gypsum and lignite humic acid application on soil organic matter and physical properties of a saline-sodic farmland soil in Eastern China. J. Soils Sediments 2016, 16, 2175-2185. [CrossRef] 
26. Qadir, M.; Ghafoor, A.; Murtaza, G. Amelioration strategies for saline soils: A review. Land Degrad. Dev. 2000, 11, 501-521. [CrossRef]

27. Abhayawickrama, B.; Gimhani, D.; Kottearachchi, N.; Herath, V.; Liyanage, D.; Senadheera, P. In Silico identification of QTL-based polymorphic genes as salt-responsive potential candidates through mapping with two reference genomes in rice. Plants $\mathbf{2 0 2 0}$ 9, 233. [CrossRef]

28. Zhang, W.-W.; Wang, C.; Xue, R.; Wang, L. Effects of salinity on the soil microbial community and soil fertility. J. Integr. Agric. 2019, 18, 1360-1368. [CrossRef]

29. Yu, J.; Wang, Z.; Meixner, F.X.; Yang, F.; Wu, H.; Chen, X. Biogeochemical characterizations and reclamation strategies of saline sodic soil in Northeastern China. CLEAN-Soil Air Water 2010, 38, 1010-1016. [CrossRef]

30. Cheeseman, J.M. The evolution of halophytes, glycophytes and crops, and its implications for food security under saline conditions. New Phytol. 2015, 206, 557-570. [CrossRef]

31. Shrivastava, P.; Kumar, R. Soil salinity: A serious environmental issue and plant growth promoting bacteria as one of the tools for its alleviation. Saudi J. Biol. Sci. 2015, 22, 123-131. [CrossRef]

32. Tavakoli Kivi, S.; Bailey, R.T. Modeling sulfur cycling and sulfate reactive transport in an agricultural groundwater system. Agric. Water Manag. 2017, 185, 78-92. [CrossRef]

33. Bello, S.K. An overview of the morphological, genetic and metabolic mechanisms regulating phosphorus efficiency via root traits in soybean. J. Soil Sci. Plant Nutr. 2021, 21, 1013-1029. [CrossRef]

34. Yeo, A. Predicting the interaction between the effects of salinity and climate change on crop plants. Sci. Hortic. 1999, 78, 159-174. [CrossRef]

35. Tanji, K.K.; Kielen, N.C. Salinity in the soil environment. In Salinity: Environment-Plants-Molecules; Läuchli, A., Lüttge, U., Eds.; Springer: Dordrecht, The Netherland, 2002; pp. 21-51.

36. Khan, A.; Khan, A.L.; Muneer, S.; Kim, Y.H.; Al-Rawahi, A.; Al-Harrasi, A. Silicon and salinity: Crosstalk in crop-mediated stress tolerance mechanisms. Front. Plant Sci. 2019, 10, 1429. [CrossRef]

37. Safdar, H.; Amin, A.; Shafiq, Y.; Ali, A.; Yasin, R.; Shoukat, A.; Hussan, M.U.I.; Sarwar, M.I. A review: Impact of salinity on plant growth. Nat. Sci. 2019, 17, 34-40.

38. Ahanger, M.A.; Agarwal, R.M. Salinity stress induced alterations in antioxidant metabolism and nitrogen assimilation in wheat (Triticum aestivum L.) as influenced by potassium supplementation. Plant Physiol. Biochem. 2017, 115, 449-460. [CrossRef] [PubMed]

39. Lastiri-Hernández, M.A.; Alvarez-Bernal, D.; Bermúdez-Torres, K.; Cárdenas, G.C.; Ceja-Torres, L.F. Phytodesalination of a moderately saline soil combined with two inorganic amendments. Bragantia 2019, 78, 579-586. [CrossRef]

40. Roy, S.J.; Negrao, S.; Tester, M. Salt resistant crop plants. Curr. Opin. Biotechnol. 2014, 26, 115-124. [CrossRef] [PubMed]

41. Munns, R.; Tester, M. Mechanisms of salinity tolerance. Annu. Rev. Plant. Biol. 2008, 59, 651-681. [CrossRef]

42. Zhang, J.-L.; Flowers, T.J.; Wang, S.-M. Mechanisms of sodium uptake by roots of higher plants. Plant Soil 2009, 326, 45-60. [CrossRef]

43. Keisham, M.; Mukherjee, S.; Bhatla, S.C. Mechanisms of sodium transport in plants-progresses and challenges. Int. J. Mol. Sci. 2018, 19, 647. [CrossRef]

44. Byrt, C.S.; Zhao, M.; Kourghi, M.; Bose, J.; Henderson, S.W.; Qiu, J.; Gilliham, M.; Schultz, C.; Schwarz, M.; Ramesh, S.A. Non-selective cation channel activity of aquaporin AtPIP2;1 regulated by $\mathrm{Ca}^{(2+)}$ and $\mathrm{pH}$. Plant Cell Environ. 2017, 40, 802-815. [CrossRef] [PubMed]

45. Garciadeblás, B.; Senn, M.E.; Bañuelos, M.A.; Rodríguez-Navarro, A. Sodium transport and HKT transporters: The rice model. Plant J. 2003, 34, 788-801. [CrossRef]

46. Pardo, J.; Rubio, F. Na ${ }^{+}$and $\mathrm{K}^{+}$transporters in plant signaling. In Transporters and Pumps in Plant Signaling; Geisler, M., Venema, K., Eds.; Springer: Berlin/Heidelberg, Germany, 2011; Volume 7, pp. 65-98.

47. Maathuis, F.J.; Ahmad, I.; Patishtan, J. Regulation of Na(+) fluxes in plants. Front. Plant Sci. 2014, 5, 467. [CrossRef] [PubMed]

48. Gupta, B.; Huang, B. Mechanism of salinity tolerance in plants: Physiological, biochemical, and molecular characterization. Int. J. Genom. 2014, 2014, 701596. [CrossRef]

49. Jayakannan, M.; Bose, J.; Babourina, O.; Rengel, Z.; Shabala, S. Salicylic acid improves salinity tolerance in Arabidopsis by restoring membrane potential and preventing salt-induced $\mathrm{K}+$ loss via a GORK channel. J. Exp. Bot. 2013, 64, 2255-2268. [CrossRef]

50. Netondo, G.W.; Onyango, J.C.; Beck, E. Sorghum and salinity: II. gas exchange and chlorophyll fluorescence of sorghum under salt stress. Crop. Sci. 2004, 44, 806-811. [CrossRef]

51. Marschner, P. Mineral nutrition of higher plants. In Special Publications of the Society for General Microbiology, 2nd ed.; Academic Press: London, UK, 1995.

52. Peleg, Z.; Apse, M.P.; Blumwald, E. Engineering salinity and water-stress tolerance in crop plants. In Plant Responses to Drought and Salinity Stress-Developments in a Post-Genomic Era; Elsevier Ltd.: Oxford, UK, 2011; pp. 405-443.

53. Hasegawa, P.M.; Bressan, R.A.; Zhu, J.K.; Bohnert, H.J. Plant cellular and molecular responses to high salinity. Annu. Rev. Plant Physiol. Plant Mol. Biol. 2000, 51, 463-499. [CrossRef]

54. Shabala, S.; Pang, J.; Zhou, M.; Shabala, L.; Cuin, T.A.; Nick, P.; Wegner, L.H. Electrical signalling and cytokinins mediate effects of light and root cutting on ion uptake in intact plants. Plant Cell Environ. 2009, 32, 194-207. [CrossRef] [PubMed] 
55. Flowers, T.J.; Colmer, T.D. Salinity tolerance in halophytes. New Phytol. 2008, 179, 945-963. [CrossRef]

56. Stamford, N.P.; Figueiredo, M.V.B.; Junior, S.S.; Freitas, A.D.S.; Santos, C.E.R.S.; Junior, M.A.L. Effect of gypsum and sulfur with Acidithiobacillus on soil salinity alleviation and on cowpea biomass and nutrient status as affected by PK rock biofertilizer. Sci. Hortic. 2015, 192, 287-292. [CrossRef]

57. Wang, W.; Xu, Y.; Chen, T.; Xing, L.; Xu, K.; Xu, Y.; Ji, D.; Chen, C.; Xie, C. Regulatory mechanisms underlying the maintenance of homeostasis in Pyropia haitanensis under hypersaline stress conditions. Sci. Total Environ. 2019, 662, 168-179. [CrossRef]

58. Wang, S.J.; Chen, Q.; Li, Y.; Zhuo, Y.Q.; Xu, L.Z. Research on saline-alkali soil amelioration with FGD gypsum. Resour. Conserv. Recycl. 2017, 121, 82-92. [CrossRef]

59. Kim, H.S.; Kim, K.-R.; Lee, S.-H.; Kunhikrishnan, A.; Kim, W.-I.; Kim, K.-H. Effect of gypsum on exchangeable sodium percentage and electrical conductivity in the Daeho reclaimed tidal land soil in Korea-A field scale study. J. Soils Sediments 2016, 18, 336-341. [CrossRef]

60. Alcívar, M.; Zurita-Silva, A.; Sandoval, M.; Muñoz, C.; Schoebitz, M. Reclamation of saline-sodic soils with combined amendments: Impact on quinoa performance and biological soil quality. Sustainability 2018, 10, 3083. [CrossRef]

61. Shainberg, I.; Sumner, M.E.; Miller, W.P.; Farina, M.P.W.; Pavan, M.A.; Fey, M.Y. Use of Gypsum on Soils: A Review. Adv. Soil Sci. 1989, 9, 1-111.

62. Abd El-Hady, M.; Shaaban, S.M. Acidification of saline irrigation water as a water conservation technique and its effect on some soil properties. Am.-Eurasian J. Agric. Environ. Sci. 2010, 7, 463-470.

63. Cifuentes, F.R.; Lindemann, W.C. Organi matter stimulation of elemental sulfur oxidation in a calcareous soil. Soil Sci. Soc. Am. J. 1993, 57, 727-731. [CrossRef]

64. Weil, R.R.; Brady, N.C. The Nature and Properties of Soils, 15th ed.; Pearson: England, UK, 2017.

65. Mahmoodabadi, M.; Yazdanpanah, N.; Sinobas, L.R.; Pazira, E.; Neshat, A. Reclamation of calcareous saline sodic soil with different amendments (I): Redistribution of soluble cations within the soil profile. Agric. Water Manag. 2013, 120, 30-38. [CrossRef]

66. Aboelsoud, H.; Engel, B.; Gad, K. Effect of planting methods and gypsum application on yield and water productivity of wheat under salinity conditions in North Nile Delta. Agronomy 2020, 10, 853. [CrossRef]

67. Cramer, G.R. Kinetics of maize leaf elongation. J. Exp. Bot. 1992, 43, 857-864. [CrossRef]

68. Grieve, C.; Grattan, S. Mineral nutrient acquisition and response by plants grown in saline environments. In Handbook of Plant and Crop Stress, 2nd ed.; Pessarakli, M., Ed.; CRC Press: Boca Raton, FL, USA, 1999; pp. 203-229.

69. Kelly, J.; Rengasamy, P. Diagnosis and Management of Soil Constraints: Transient Salinity, Sodicity and Alkalinity; The University of Adelaide and Grain Research and Development Corporation: Adelaide, Australia, 2006.

70. Wheaton, A.D.; McKenzie, B.M.; Tisdall, J.M. Management of a sodic soil for wine grape production. Aust. J. Exp. Agric. 2002, 42, 333-339. [CrossRef]

71. Shalaby, O.A.E.-S. Alleviation of salinity stress in red cabbage plants by urea and sulfur applications. J. Plant Nutr. 2018, 41, 1597-1603. [CrossRef]

72. Riffat, A.; Ahmad, M.S.A. Alleviation of adverse effects of salt stress on growth of maize (Zea mays L.) by sulfur supplementation. Pak. J. Bot. 2020, 52, 763-773. [CrossRef]

73. Silva, M.L.d.S.; Trevizam, A.R.; Piccolo, M.C.; Furlan, G. Tomato production in function of sulfur doses application. Rev. Bras. Tecnol. Apl. Ciências Agrárias 2014, 7, 47-54. [CrossRef]

74. McKenna, B.A.; Kopittke, P.M.; Macfarlane, D.C.; Dalzell, S.A.; Menzies, N.W. Changes in soil chemistry after the application of gypsum and sulfur and irrigation with coal seam water. Geoderma 2019, 337, 782-791. [CrossRef]

75. Day, S.J.; Norton, J.B.; Strom, C.F.; Kelleners, T.J.; Aboukila, E.F. Gypsum, langbeinite, sulfur, and compost for reclamation of drastically disturbed calcareous saline-sodic soils. Int. J. Environ. Sci. Technol. 2018, 16, 295-304. [CrossRef]

76. Scherer, H.W. Sulphur in crop production-Invited paper. Eur. J. Agron. 2001, 14, 81-111. [CrossRef]

77. Hasanuzzaman, M.; Bhuyan, M.; Mahmud, J.A.; Nahar, K.; Mohsin, S.M.; Parvin, K.; Fujita, M. Interaction of sulfur with phytohormones and signaling molecules in conferring abiotic stress tolerance to plants. Plant Signal Behav. 2018, 13, e1477905. [CrossRef]

78. Nazar, R.; Iqbal, N.; Masood, A.; Syeed, S.; Khan, N.A. Understanding the significance of sulfur in improving salinity tolerance in plants. Environ. Exp. Bot. 2011, 70, 80-87. [CrossRef]

79. Fatma, M.; Masood, A.; Per, T.S.; Rasheed, F.K.; Nafees, A. Interplay between nitric oxide and sulfur assimilation in salt tolerance in plants. Crop. J. 2016, 4, 153-161. [CrossRef]

80. Lewandowska, M.; Sirko, A. Recent advances in understanding plant response to sulfur-deficiency stress. Acta Biochim. Pol. 2008, 55, 457-471. [CrossRef]

81. Koralewska, A.; Stuiver, C.E.E.; Posthumus, F.S.; Kopriva, S.; Hawkesford, M.J.; de Kok, L.J. Regulation of sulfate uptake, expression of the sulfate transporters Sultr1;1 and Sultr1;2, and APS reductase in Chinese cabbage (Brassica pekinensis) as affected by atmospheric H2S nutrition and sulfate deprivation. Funct. Plant Biol. 2008, 35, 318-327. [CrossRef] [PubMed]

82. Mazid, M.; Khan, T.M.; Mohammad, F. Response of crop plants under sulphur stress tolerance. J. Stress Physiol. Biochem. 2011, 7, 25-57.

83. Hawkesford, M.J.; de Kok, L.J. Managing sulphur metabolism in plants. Plant Cell Environ. 2006, 29, 382-395. [CrossRef] [PubMed] 
84. Fatma, M.; Khan, M.I.R.; Masood, A.; Khan, N.A. Coordinate changes in assimilatory sulfate reduction are correlated to salt tolerance: Involvement of phytohormones. Annu. Rev. Res. Biol. 2013, 3, 267-295.

85. Iqbal, N.; Masood, A.; Khan, M.I.; Asgher, M.; Fatma, M.; Khan, N.A. Cross-talk between sulfur assimilation and ethylene signaling in plants. Plant Signal Behav. 2013, 8, e22478. [CrossRef]

86. Nazar, R.; Umar, S.; Khan, N.A. Exogenous salicylic acid improves photosynthesis and growth through increase in ascorbateglutathione metabolism and S assimilation in mustard under salt stress. Plant Signal Behav. 2015, 10, e1003751. [CrossRef] [PubMed]

87. Chan, K.X.; Phua, S.Y.; van Breusegem, F. Secondary sulfur metabolism in cellular signalling and oxidative stress responses. J. Exp. Bot. 2019, 70, 4237-4250. [CrossRef] [PubMed]

88. Spadaro, D.; Yun, B.W.; Spoel, S.H.; Chu, C.; Wang, Y.Q.; Loake, G.J. The redox switch: Dynamic regulation of protein function by cysteine modifications. Physiol. Plant 2010, 138, 360-371. [CrossRef]

89. Gill, S.S.; Tuteja, N. Reactive oxygen species and antioxidant machinery in abiotic stress tolerance in crop plants. Plant Physiol. Biochem. 2010, 48, 909-930. [CrossRef] [PubMed]

90. Ruiz, J.M.; Blumwald, E. Salinity-induced glutathione synthesis in Brassica napus. Planta 2002, 214, 965-969. [CrossRef]

91. Abd El-Mageed, T.A.; Rady, M.M.; Taha, R.S.; Abd El Azeam, S.; Simpson, C.R.; Semida, W.M. Effects of integrated use of residual sulfur-enhanced biochar with effective microorganisms on soil properties, plant growth and short-term productivity of Capsicum annuum under salt stress. Sci. Hortic. 2020, 261, 108930. [CrossRef]

92. Kruse, C.; Jost, R.; Lipschis, M.; Kopp, B.; Hartmann, M.; Hell, R. Sulfur-enhanced defence: Effects of sulfur metabolism, nitrogen supply, and pathogen lifestyle. Plant Biol. (Stuttg.) 2007, 9, 608-619. [CrossRef]

93. Anjum, N.A.; Gill, R.; Kaushik, M.; Hasanuzzaman, M.; Pereira, E.; Ahmad, I.; Tuteja, N.; Gill, S.S. ATP-sulfurylase, sulfurcompounds, and plant stress tolerance. Front. Plant Sci. 2015, 6, 210. [CrossRef] [PubMed]

94. Khan, N.A.; Nazar, R.; Anjum, N.A. Growth, photosynthesis and antioxidant metabolism in mustard (Brassica juncea L.) cultivars differing in ATP-sulfurylase activity under salinity stress. Sci. Hortic. 2009, 122, 455-460. [CrossRef]

95. Koprivova, A.; North, K.A.; Kopriva, S. Complex signaling network in regulation of adenosine $5^{\prime}$-phosphosulfate reductase by salt stress in Arabidopsis roots. Plant Physiol. 2008, 146, 1408-1420. [CrossRef] [PubMed]

96. Fatma, M.; Asgher, M.; Masood, A.; Khan, N.A. Excess sulfur supplementation improves photosynthesis and growth in mustard under salt stress through increased production of glutathione. Environ. Exp. Bot. 2014, 107, 55-63. [CrossRef]

97. Perveen, S.; Iqbal, N.; Saeed, M.; Zafar, S.; Arshad, Z. Role of foliar application of sulfur-containing compounds on maize (Zea mays L. var. Malka and hybrid DTC) under salt stress. Braz. J. Bot. 2018, 41, 805-815. [CrossRef]

98. ur Rehman, H.; Iqbal, Q.; Farooq, M.; Wahid, A.; Afzal, I.; Basra, S.M.A. Sulphur application improves the growth, seed yield and oil quality of canola. Acta Physiol. Plant. 2013, 35, 2999-3006. [CrossRef]

99. Krischan, J.; Makaruk, A.; Harasek, M. Design and scale-up of an oxidative scrubbing process for the selective removal of hydrogen sulfide from biogas. J. Hazard Mater. 2012, 215-216, 49-56. [CrossRef] [PubMed]

100. Osman, A.S.; Rady, M.M. Ameliorative effects of sulphur and humic acid on the growth, anti-oxidant levels, and yields of pea (Pisum sativum L.) plants grown in reclaimed saline soil. J. Hortic. Sci. Biotechnol. 2015, 87, 626-632. [CrossRef]

101. Zayed, B.; Abdelaal, M.; Deweedar, G. Response of rice yield and soil to sulfur application under water and salinity stresses. Egypt. J. Agron. 2017, 39, 239-249. [CrossRef]

102. Abd El-Naby, Z.M.; Hafez, W.A.E.-K.; Hashem, H.A. Remediation of salt-affected soil by natural and chemical amendments to improve berseem clover yield and nutritive quality. Afr. J. Range Forage Sci. 2018, 36, 49-60. [CrossRef]

103. Ahmed, K.; Qadir, G.; Jami, A.-R.; Nawaz, M.Q.; Rehim, A.; Jabran, K.; Hussain, M. Gypsum and farm manure application with chiseling improve soil properties and performance of fodder beet under saline-sodic conditions. Int. J. Agric. Biol. 2015, 17, 1225-1230. [CrossRef]

104. Kitila, K.; Chala, A.; Workina, M. Effect of Gypsum and compost Application in Reclaiming Sodic soils at Small Scale Irrigation Farm in Bora District of East Shewa Zone, Oromia, Ethiopia. Agriways 2020, 08, 28-44. [CrossRef]

105. Nouri, H.; Chavoshi Borujeni, S.; Nirola, R.; Hassanli, A.; Beecham, S.; Alaghmand, S.; Saint, C.; Mulcahy, D. Application of green remediation on soil salinity treatment: A review on halophytoremediation. Process. Saf. Environ. Prot. 2017, 107, 94-107. [CrossRef]

106. Tanji, K.; Kielen, N. Agricultural drainage water management in arid and semi-arid areas. In FAO Irrigation and Drainage Paper 61, Annex 1: Crop Salt Tolerance Data; FAO: Rome, Italy, 2003.

107. Chartzoulakis, K.S. Salinity and olive: Growth, salt tolerance, photosynthesis and yield. Agric. Water Manag. 2005, 78, 108-121. [CrossRef]

108. Zuazo, V.H.D.; Raya, A.M.n.; Ruiz, J.A. Impact of salinity on the fruit yield of mango (Mangifera indica L. cv. 'Osteen'). Eur. J. Agron. 2004, 21, 323-334. [CrossRef]

109. Paranychianakis, N.V.; Chartzoulakis, K.S. Irrigation of Mediterranean crops with saline water: From physiology to management practices. Agric. Ecosyst. Environ. 2005, 106, 171-187. [CrossRef]

110. Panta, S.; Flowers, T.; Lane, P.; Doyle, R.; Haros, G.; Shabala, S. Halophyte agriculture: Success stories. Environ. Exp. Bot. 2014, 107, 71-83. [CrossRef] 
111. Abate, S.; Belayneh, M.; Ahmed, F.; Tejada Moral, M. Reclamation and amelioration of saline-sodic soil using gypsum and halophytic grasses: Case of Golina-Addisalem irrigation scheme, Raya Kobo Valley, Ethiopia. Cogent Food Agric. 2021, 7, 1859847. [CrossRef]

112. Bello, S.K.; Yusuf, A.A. Phosphorus influences the performance of mycorrhiza and organic manure in maize production. J. Plant Nutr. 2021, 44, 679-691. [CrossRef]

113. Mbarki, S.; Cerda, A.; Brestic, M.; Mahendra, R.; Abdelly, C.; Pascual, J.A. Vineyard compost supplemented with Trichoderma Harzianum T78 improve saline soil quality. Land Degrad. Dev. 2017, 28, 1028-1037. [CrossRef]

114. Krishnamoorthy, R.; Kim, K.; Subramanian, P.; Senthilkumar, M.; Anandham, R.; Sa, T. Arbuscular mycorrhizal fungi and associated bacteria isolated from salt-affected soil enhances the tolerance of maize to salinity in coastal reclamation soil. Agric. Ecosyst. Environ. 2016, 231, 233-239. [CrossRef]

115. Xu, J.; Tang, X.; Shao, H.; Wang, H. The foliar spray of Rhodopseudomonas palustris grown under Stevia residue extract promotes plant growth via changing soil microbial community. J. Soils Sediments 2015, 16, 916-923. [CrossRef]

116. Bacilio, M.; Moreno, M.; Bashan, Y. Mitigation of negative effects of progressive soil salinity gradients by application of humic acids and inoculation with Pseudomonas stutzeri in a salt-tolerant and a salt-susceptible pepper. Appl. Soil Ecol. 2016, 107, 394-404. [CrossRef]

117. Wagner, K.; Apostolakis, A.; Daliakopoulos, I.; Tsanis, I. Can tomato inoculation with Trichoderma compensate yield and soil health deficiency due to soil salinity? In Proceedings of the EGU (European Geosciences Union) General Assembly Conference, Vienna, Austria, 17-22 April 2016; Geophysical Research Abstracts; EGU2016-1007; EGU: Vienna, Austria, 2016.

118. Daliakopoulos, I.N.; Apostolakis, A.; Wagner, K.; Deligianni, A.; Koutskoudis, D.; Stamatakis, A.; Tsanis, I.K. Effectiveness of Trichoderma harzianum in soil and yield conservation of tomato crops under saline irrigation. Catena 2019, 175, 144-153. [CrossRef]

119. Leithy, S.; Gaballah, M.; Goma, A. Associative impact of bio- and organic fertilizers on geranium plants grown under saline conditions. Int. J. Acad. Res. 2009, 1, 17-23.

120. Jha, Y.; Subramanian, R.B. PGPR regulate caspase-like activity, programmed cell death, and antioxidant enzyme activity in paddy under salinity. Physiol. Mol. Biol. Plants 2014, 20, 201-207. [CrossRef] [PubMed]

121. Miltner, A.; Richnow, H.-H.; Kopinke, F.-D.; Kästner, M. Incorporation of carbon originating from $\mathrm{CO}_{2}$ into different compounds of soil microbial biomass and soil organic matter. Isot. Environ. Health Stud. 2005, 41, 135-140. [CrossRef] [PubMed]

122. Ontl, T.; Schulte, L. Soil Carbon Storage. Nat. Educ. Knowl. 2012, 3, 35. Available online: https://www.nature.com/scitable/ knowledge/library/soil-carbon-storage-84223790/ (accessed on 20 August 2021).

123. Khatun, M.; Shuvo, M.A.R.; Salam, M.T.B.R.; Hafizur, S.M. Effect of organic amendments on soil salinity and the growth of maize (Zea mays L.). Plant Sci. Today 2019, 6, 106-111. [CrossRef]

124. Ondrasek, G.; Rengel, Z. Environmental salinization processes: Detection, implications \& solutions. Sci. Total Environ. 2021, 754, 142432. [PubMed]

125. Gómez, I.; Navarro-Pedreño, J.; Mataix, J. The influence of saline irrigation and organic waste fertilisation on the mineral content (N, P, K, Na, Ca and Mg) of tomatoes. J. Sci. Food Agric. 1992, 59, 483-487. [CrossRef]

126. Abdel-Fattah, M.K. Role of gypsum and compost in reclaiming saline-sodic soils. J. Agric. Vet. Sci. 2012, 1, 30-38. [CrossRef]

127. Shaaban, M.; Abid, M.; Abou, S. Amelioration of salt affected soils in rice paddy system by application of organic and inorganic amendments. Plant Soil Environ. 2013, 59, 227-233. [CrossRef]

128. Vance, W.H.; Tisdall, J.M.; McKenzie, B.M. Residual effects of surface applications of organic matter and calcium salts on the subsoil of a red-brown earth. Aust. J. Exp. Agric. 1998, 38, 595-600. [CrossRef]

129. Sahin, U.; Eroğlu, S.; Sahin, F. Microbial application with gypsum increases the saturated hydraulic conductivity of saline-sodic soils. Appl. Soil Ecol. 2011, 48, 247-250. [CrossRef]

130. Bayoumy, M.; Khalifa, T.; Aboelsoud, H. Impact of some organic and inorganic amendments on some soil properties and wheat production under saline-sodic soil. J. Soil Sci. Agric. Eng. 2019, 10, 307-313. [CrossRef] 